\title{
Taxpayer Compliance from the Perspective of Slippery Slope Theory: An Experimental Study
}

\author{
I Nyoman Putra Yasa ${ }^{*}$, I Putu Hendra Martadinata ${ }^{2}$ \\ 1,2 Universitas Pendidikan Ganesha, Jalan Udayana No.11 Singaraja, Bali, Indonesia \\ *Corresponding author; Email: putrayasainym@undiksha.ac.id
}

\begin{abstract}
The aims of this research is to do relevance on taxpayer compliance attitude based on slippery slope theory. The method used in this research is an experimental method with 63 taxpayers as the samples. The result of this research found that taxpayer trust level on tax authority has a positive and significant influence on taxpayer willingness to pay their tax, while tax authority's power in watching over taxation process does not affect voluntary taxpayer compliance in paying tax. The highest voluntary taxpayer compliance rate is shown by the taxpayer with high trust in tax authority and has strong tax authority. On the other hand, the lowest voluntary taxpayer compliance rate is shown by the taxpayer with low trust on tax authority and have weak tax authority. In summary, this research supported the slippery slope theory and is hoped to be able to strengthen the relevance of slippery slope theory in explaining taxpayer compliance attitude.
\end{abstract}

Keywords: Slippery slope theory, trust, power, taxpayer compliance.

\section{INTRODUCTION}

It is a fact that every country in this world needs to have a huge amount of fund in order to do their activities, including Indonesia. Indonesia needs an overwhelming amount of fund in order to have a good governance, whether for funding or debt payments. As quoted from [6], the total government revenue that was arranged in State Budget (Anggaran Penerimaan dan Belanja Negara) 2018 is Rp 1.894,7 trillion. From that number, the expected source of government revenue is from Tax with $\mathrm{Rp} 1.618,1$ trillion (85,40\%), Non-Tax Revenue Rp 275,4 trillion (14,5\%) and Grant Rp 1,2 trillion (0,1\%).

Seeing the amount of government revenue that came from the tax sector, the government did everything they could to secure it, two of which are the Sunset Policy in 2015 and Tax Amnesty in 2016, as well as making taxation laws to increase taxpayer's compliance. This program resulted in a positive impact on the income from taxpayer compliance. As written in [2], government revenue from the tax sector in 2017 was Rp 1.151 trillion or $89,9 \%$ from the revenue target in State Budget 2017. Looking at taxpayer compliance, from 16,6 million taxpayer, 12,05 million taxpayer gives Tax Return, the highest compliance ration ever recorded by DGT.

In correlation with the compliance ratio, Small Tax Office (STO) Singaraja experienced the same increase of taxpayer compliance. According to [1], taxpayer compliance ration in STO Singaraja in 2016 is $70 \%$, increased from $68 \%$ in 2015 and 2014.

This research focused on the phenomenon of taxpayer compliance increase in Buleleng Regency that was tested with an experimental technique that was based on the slippery slope theory. The slippery slope theory is a theory that uses an approach based on the behavioral paradigm of the taxpayer. [5] stated that results of research that talked about a slippery slope are still inconsistent, especially for tax authority power variable. Aside from that, [10] suggested further research, one of them is experimental study to further examine the slippery slope model empirically. Because of that, this research is done to add an empirical study on the slippery slope theory so that it could strengthen the relevance of that theory to describe taxpayer compliance behavior.

\section{Taxpayer Compliance}

Compliance is a condition where taxpayer compelled and aware of their tax responsibility [13]. Generally, theories on compliance can be grouped into Force Theory and Consensus Theory. According to Force Theory, people who abide the law because of the element of coercion from government's legal authorities. This is in line with the effort to realize voluntary taxpayer compliance. 
There are two types of compliance, formal compliance and material compliance. Formal compliance is a condition where taxpayer fulfilling their responsibility formally as stated in Indonesian Taxation Law. Material compliance is a condition where taxpayer fulfills all tax material regulations.

\section{Slippery Slope Theory}

Slippery slope theory is one of the theories that is used by some researchers to study taxpayer compliance in recent years. This theory sees the social-psychological variable to be as important as deterrence variables such as tax inspection tariffs, and tax fine [7] [12]. This theory stated that socialpsychology and deterrence variables have a positive influence on tax compliance. Social-psychological variables tend to affect voluntary tax compliance, while deterrence variables tend to affect tax compliance caused by the fear of negative consequences (enforced tax compliance) [8].

Aside from that, slippery slope theory also stated that policies that aim to increase voluntary tax compliance depend on the people's trust in authorities. Policies such as inspection and tax fine tend to increase the perception of the power of authorities that will affect enforce tax compliance. Based on this slippery slope, people trust gain policies on tax authority should be prioritized in order to increase voluntary tax compliance [8] [11].

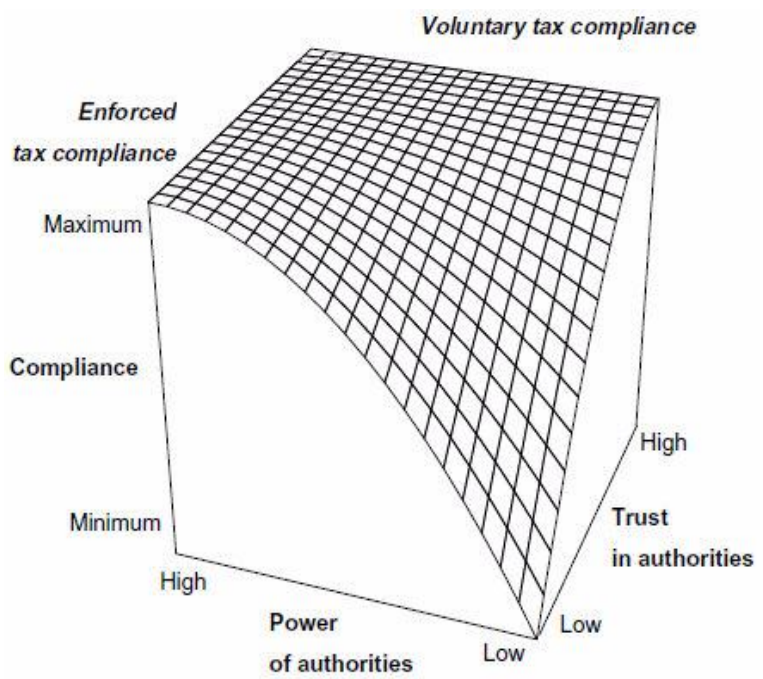

Figure 1. Slippery Slope Theory Model [7]

\section{Hypothesis Development}

Based on the slippery slope theory, two main factors that affect taxpayer compliance is the trust that taxpayer has to tax authority in watching over the tax process [7]. The taxpayer will voluntary pay their task if they really trust the tax process held by the taxpayer without being affected by tax authority's power of influence [7]. There will be a high voluntary taxpayer compliance rate if taxpayer trust is supported by a strict tax inspection. However, it would be a still high even if the tax inspection is lenient. This is going in accordance to the research done by [3], who found that taxpayer trust to tax authority could push them to voluntary pay their tax without even considering tax authority's power of influence.

Different compliance is shown if the taxpayer has low trust in tax authority. In a condition where the taxpayer has low trust and tax authority is weak, the taxpayer would be compelled to evade their tax because they feel that it is safe to do that violation, as a result of tax authority weakness in overviewing tax process. Based on research by [14], that condition caused a low rate of voluntary taxpayer compliance. However, even when taxpayer trust level is low, if the tax authority has high power in overviewing tax process, taxpayer would be afraid to evade paying tax so that they would be forced to pay their tax, even if that compliance is forced (voluntary taxpayer compliance is low) [3] [5] [7]. Based on that framework, the proposed hypotheses are:

H1: There is no significant difference in compliance rate between taxpayer high trust on tax authority and having strong tax authority with taxpayer low trust on tax authority and having weak tax authority.

H2: Taxpayer with high trust on tax authority and have a strong tax authority show a higher voluntary compliance than the taxpayer with low trust and strong tax authority.

H3: Taxpayer with high trust on tax authority and have a strong tax authority show a higher voluntary compliance than the taxpayer with low trust and weak tax authority.

H4: Taxpayer with high trust on tax authority and have a weak tax authority show higher voluntary compliance than the taxpayer with low trust on tax authority and have strong tax authority.

H5: Taxpayer with high trust on tax authority and have weak tax authority show higher voluntary compliance than the taxpayer with low trust on tax authority and have weak tax authority

H6: There is no significant difference between taxpayer with low trust on tax authority and have a strong tax authority with taxpayer with low trust on tax authority and have a weak tax authority. 


\section{RESEARCH METHOD}

\section{Experimental design}

Hypothesis test on this research used the experimental method with $2 \times 2$ between-subject design. "Trust" and "power" variables are used as a treatment in this experiment. The participants consist of the randomly chosen taxpayer. There are four experimental groups that are grouped by the variables used in this research. Below are brief descriptions of the four groups used in this experiment:

1. Group A: this group is given "high trust" and "high power" treatment scenario.

2. Group B: this group is given "high trust" and "low power" treatment scenario.

3. Group C: this group is given "low trust" and "high power" treatment scenario.

4. Group D: this group is given "low trust" and "low power" treatment scenario.

This research's experimental design can be seen in the table 1.

Table 1. Experimental Design

\begin{tabular}{ccc}
\hline \multirow{2}{*}{ TRUST } & \multicolumn{2}{c}{ POWER } \\
\cline { 2 - 3 } & High & Low \\
\hline High & A & B \\
Low & C & D \\
\hline
\end{tabular}

\section{Method of Collecting Data}

The data collection is done by spreading research instruments to each participant. Here are the steps of collecting data for this research:

1. Research instruments are given to the participants.

2. Participants are directed to read case material and are asked to give responses to the given case.

3. Participants are asked to answer manipulation check answer and fill in their biodata.

\section{Operational Definition and Variable Measurement}

Independent variables in this research are trusted (on tax authority) and power (of the tax authority), while the dependent variable is voluntary taxpayer compliance. The 'trust' in this research means the view from individuals or social groups that tax authority works well for common interest [14]. Power is the perception of the taxpayer on the ability of tax authority to overview the tax process in their region or nation [14], while voluntary taxpayer compliance is their awareness to voluntary fulfill their responsibility as a taxpayer [13].

Trust and Power are used as experimental treatment. To measure voluntary taxpayer compliance rate, this research used a Likert 5 points scale. This research used a case study that was adapted from the experiments done by [14]. In that instrument, there is a description of a fictional country on which the trust level and tax authority power are fixed for each group's experimental treatment. Participants were asked to imagine themselves as citizens on that case and were asked to show voluntary taxpayer rate in that country.

\section{Data Analysis Technique}

This hypothesis test is done by using two-way analysis of variance (ANOVA) method to test the interaction between research variables (power and trust) with signification standard (a) $=0,05$. ANOVA assumption and hypothesis test are done with the help of the Statistical Package for the Social Sciences (SPSS) version 19.

\section{RESULT AND DISCUSSION}

\section{Data Description}

This experiment is done to 63 Singaraja taxpayers. The taxpayers were randomly chosen and were invited to become participants. The participants consist of 24 men $(38,10 \%)$ and 39 women $(61,90 \%)$. The average age of the participants is 32 .

Participants are grouped into four treatment groups: (1) High Trust-High Power; (2) High TrustLow Power; (3) Low Trust-High Power; (4) Low Trust-Low Power. The grouping was done randomly. After the participant's data was being gathered, the data show that there are reasons differences regarding participants' voluntary in paying taxes on each treatment groups. Below is the data description table gathered from this research.

Table 2. Demographic Data

\begin{tabular}{llcc}
\hline \multicolumn{2}{c}{ Information } & Amount & Percentage (\%) \\
\hline \multirow{2}{*}{ Gender } & Men & 24 & 38,10 \\
& Women & 39 & 61,90 \\
\cline { 2 - 4 } & Total & 63 & 100,00 \\
\hline \multirow{2}{*}{ Age } & $\leq 30$ & 28 & 44,44 \\
& $31-40$ & 31 & 49,21 \\
& $>40$ & 4 & 6,35 \\
\cline { 2 - 4 } & Total & 63 & 100,00 \\
\hline
\end{tabular}


Table 3. Participants' Responses Based on Trust and Power

\begin{tabular}{clcc}
\hline \multicolumn{2}{c}{ Status } & \multicolumn{2}{c}{ Number of Voluntary Score } \\
Participants & Average \\
\hline \multirow{2}{*}{ Treatment } & High Trust & 32 & 3,97 \\
Groups & Low Trust & 31 & 2,10 \\
& High Power & 32 & 3,19 \\
& Low Power & 31 & 2,90 \\
\hline
\end{tabular}

Table 4. Participants' Responses Based on the Combination Between Trust and Power

\begin{tabular}{llcc}
\hline \multicolumn{1}{c}{ Status } & $\begin{array}{c}\text { Number of } \\
\text { Participants }\end{array}$ & $\begin{array}{c}\text { Voluntary } \\
\text { Score Average }\end{array}$ \\
\hline Treatment & High Trust- & 17 & 4,12 \\
Groups & $\begin{array}{l}\text { High Power } \\
\text { High Trust- }\end{array}$ & 15 & 3,80 \\
$\begin{array}{l}\text { Low Power } \\
\text { Low Trust- }\end{array}$ & 15 & 2,13 \\
$\begin{array}{l}\text { High Power } \\
\text { Low Trust-Low } \\
\text { Power }\end{array}$ & 16 & 2,06 \\
\hline
\end{tabular}

From Table 4. it is clear that both High-TrustHigh Power and High Trust-Low Power groups have high voluntary taxpayer compliance rate (their score is higher than the questionnaire's median, 3), while Low Trust-High Power and Low Trust-Low Power groups have low voluntary taxpayer compliance (their score is lower than the questionnaire's median, 3). The highest voluntary rate is shown by the High Trust-High Power group (voluntary score 4,12), while the lowest is shown by Low Trust-Low Power group (voluntary score 2,06).

\section{Hypothesis Test}

Before executing the ANOVA test, the researcher has done the normality and homogeneity test. From Levene's test, the researcher found Sig. value of $0,711(p>0,05)$. That founding shows that the data is homogenous. Normality test, however, found that the data is not normal. The cause was the tendency or skewness of this data. ANOVA test is still a robust event though there is an abnormal data distribution that was caused by the skewness of data distribution [4]. Thus the ANOVA hypothesis test was still being continued.

To test the main effect and interaction between the two independent variables, Trust and Power, the researcher used a two-way ANOVA test with gender and age as the controlling variable. The result can be seen in the table 5 .

Based on the data in Table 5, it could be seen that the main effect for Trust variable shows a significant result with Sig. value of $0,000(p<0,01)$. Meanwhile, the main effect of Power shows the non-significant result with Sig. value of 0,334 ( $p>$ $0,05)$. For Trust and Power interaction (Trust *
Power), the ANOVA test result shows a nonsignificant result with Sig. value of 0,538 ( $p>0,05)$.

Next, the researcher did ANOVA post hoc test by using Tukey's HSD method. This test was done to understand the signification of differences in voluntary taxpaying rate between the groups. Below is the post hoc test result by using Tukey's HSD method for each group.

From Table 6, it can be seen that there is a significant difference in voluntary taxpaying rate between the groups: (1) High Trust-High Power and Low Trust-High Power; (2) High Trust-High Power and Low Trust-Low Power; (3) High TrustLow Power and Low Trust-High Power; and (4) High Trust-Low Power and Low Trust-Low Power with Sig. value of $0,000(p<0,05)$ each. From that result, is known that Hypothesis 2, 3, 4, and 5 are supported.

\section{Discussion}

According to the slippery slope theory, taxpayer trust on tax authority and the power of tax authority are two important factors that affect taxpayer into voluntary paying their tax [7]. The taxpayer will voluntary pay their tax if their trust on tax authority is high, supported by tax authority with power to overview the taxpayers [7]. On the other hand, taxpayer tends to avoid their responsibility to pay tax if the taxpayer has low trust and tax authority do not have the power to overview the taxpayers [7].

This research found that taxpayer trust on tax authority positively, and significantly, influence their voluntary compliance. This fits with slippery slope theory and the experiment that was done by [3] and [14]. Taxpayers believe that the tax that they paid to tax authority is being used as it should by the country, and that grows a synergic relation between taxpayer and tax authority [7] [14]. In other words, maximum services and government's honesty in handling the fund originated from the taxpayer will make the taxpayer trust them, so the taxpayer will voluntary pay their tax.

However, for the trust variable, this research found that tax authority's power does not affect voluntary taxpayer compliance. Although the direction of the data went according to slippery slope theory (voluntary taxpayer compliance on High Power treatment $(3,19)>$ Low Power $(2,97)$ ), there is no significant result from that difference. Aside from that, this research could not found a significant interaction between trust and fear variable. As a result, this researcher did multiple comparison tests with Tukey's HSD method to find experimental groups that have significant response difference(s), as shown in Table 6. 
Table 5. ANOVA Test Result

\begin{tabular}{|c|c|c|c|c|c|}
\hline Source & $\begin{array}{c}\text { Type III Sum of } \\
\text { Squares }\end{array}$ & $\mathrm{df}$ & Mean Square & $\mathrm{F}$ & Sig. \\
\hline Corrected Model & $56.022^{\mathrm{a}}$ & 3 & 18.674 & 29.910 & .000 \\
\hline Intercept & 576.212 & 1 & 576.212 & 922.927 & .000 \\
\hline Trust & 54.394 & 1 & 54.394 & 87.124 & .000 \\
\hline Power & .593 & 1 & .593 & .949 & .334 \\
\hline Trust * Power & .239 & 1 & .239 & .383 & .538 \\
\hline Error & 36.836 & 59 & .624 & & \\
\hline Total & 678.000 & 63 & & & \\
\hline Corrected Total & 92.857 & 62 & & & \\
\hline
\end{tabular}

a. $\mathrm{R}$ Squared $=.603$ (Adjusted R Squared $=.583$ )

Table 6. Tukey's HSD Post Hoc Test Result

\begin{tabular}{llccr}
\hline \multicolumn{1}{c}{ (I) Group } & \multicolumn{1}{c}{ (J) Group } & Mean Difference (I-J) & Std. Error & Sig. \\
\hline High Trust-High Power & High Trust - Low Power & .32 & .280 & .670 \\
& Low Trust - High Power & $1.98^{*}$ & .280 & .000 \\
& Low Trust - Low Power & $2.06^{*}$ & .275 & .000 \\
High Trust-Low Power & High Trust - High Power & -.32 & .280 & .670 \\
& Low Trust - High Power & $1.67^{*}$ & .289 & .000 \\
& Low Trust - Low Power & $1.74^{*}$ & .284 & .000 \\
Low Trust-High Power & High Trust - High Power & $-1.98^{*}$ & .280 & .000 \\
& High Trust - Low Power & $-1.67^{*}$ & .289 & .000 \\
Low Trust-Low Power & Low Trust - Low Power & .07 & .284 & .994 \\
& High Trust - High Power & $-2.06^{*}$ & .275 & .284 \\
& High Trust - Low Power & $-1.74^{*}$ & .284 & .000 \\
& Low Trust - High Power & -.07 & & .994 \\
\hline
\end{tabular}

*. The mean difference is significant at the .05 level.

Based on the data from Table 6, there is no significant difference on compliance between the high trust on high power tax authority and high power $(4,12)$ and taxpayer with low trust on tax authority and low power tax authority, thus, Hypothesis 1 is supported. A taxpayer with high trust in high power tax authority shows high voluntary compliance, consistent with the result of [14] experiment. Although there is a difference in power, it does not cause any significant difference in taxpayer compliance, and both conditions show a high rate of taxpayer compliance. The findings of this research supported the slippery slope theory, that if taxpayers highly trust tax authority, then their compliance rate will still be high without even being affected by tax authority's power [3] [7] [14]. In other words, trust is a really important factor in supporting taxpayer to voluntary pay their taxes.

For hypothesis 2, this research found that taxpayers with high trust on high power tax authority have a higher voluntary compliance from the taxpayer with low trust on high power tax authority, and thus Hypothesis 2 is supported. In accordance with slippery slope theory, high trust on high power tax authority pushes taxpayer to voluntarily compelled in paying their taxes [3] [7], as shown by the 4,12 score that shows high voluntary compliance rate. On the other hand, low trust in strong tax authority shows low voluntary compliance rate of 2,13 . The low trust tends to cause the taxpayer to do tax evasion. However, the high power of tax authority caused them to pay their tax, though forcefully [3] [5] [7]. In other words, forced compliance will lower the voluntary compliance score. It is found in this research that the condition of low trust on high power tax authority shows low voluntary compliance score $(2,13)$, consistent with the slippery slope theory.

For hypothesis 3, this research found that taxpayer with high trust in high tax authority shows a higher voluntary compliance rate than the taxpayer with low trust in weak tax authority, this Hypothesis 3 is supported. The lowness of taxpayer's trust, worsened by the low power tax authority, caused the taxpayer to have low voluntary compliance rate, as proved by their voluntary compliance score: 2,06 , the lowest score amongst the experimental group. In accordance to slippery slope theory, taxpayer compliance is at the lowest level if the taxpayer has low trust on tax authority who have no power that could push the taxpayer to pay their tax [7]. 
For hypotheses 4 and 5, this research found a result that supported these two hypotheses, that taxpayer with high trust in low power tax authority (compliance score 3,80) shows higher voluntary compliance rate than taxpayer with low trust on high power tax authority (compliance score 2,13), also when compared when taxpayer with low trust on low power tax authority (compliance score 2,06). This finding shows that trust is the most important factor in building taxpayer compliance. Although having a high power, taxpayer voluntary compliance will still be low if the taxpayer does not have the trust in tax authority. On the other hand, even if the tax authority is weak in overviewing the tax process, it does not become an obstacle for taxpayers compliance to pay their tax if the taxpayers have high trust on the government of tax authority.

For hypothesis 6, this research did not find any significant differences on voluntary compliance between taxpayer with low trust in high power tax authority and taxpayer with low trust in low power tax authority. This is in accordance with the conjecture that low trust and weak tax authority caused the taxpayer to have the tendency to maximize their own benefits by not paying the tax [7]. Although tax authority has the power, that does not help growing taxpayer voluntary compliance. A taxpayer may be paying their tax, but it was done forcefully, so their voluntary compliance score is still low. Overall, this research supported that the slippery slope theory that taxpayer's trust is the most important thing in growing their awareness and willingness to pay their tax.

\section{CONCLUSION, IMPLICATION, AND LIMITATION}

\section{Conclusion}

Based on the results, this research concludes that taxpayer's trust on tax authority is a really important factor in pushing their compliance to voluntary pay their tax. In accordance to the slippery slope theory, taxpayer compliance rate will still be high if the taxpayer has high trust on tax authority even if the tax authority have weakness in observing the tax process in their country. Although tax authority's power could increase compliance, it is a forced compliance. Thus, if a country wants to achieve an ideal taxpayer behavior, that is, where taxpayers are willing to voluntarily pay their tax, then tax authority should focus on the efforts to increase the taxpayer's trust.

\section{Implication}

Overall, this research's results support the slippery slope's framework, thus this research gives a theoretical contribution to explaining taxpayer's compliance behavior based on slippery slope theory. As far as the author knows, an experimental study on slippery slope theory had only been done by [3] [7]. A research result with this experimental method is intended to be able to strengthen the relevance of slippery slope theory in explaining taxpayer compliance behavior. Other than that, the researcher hoped the tax authority to consider the result of the research to increase taxpayer trust on tax authority, because trust is the most important factor in increasing taxpayer's voluntariness in paying their tax.

\section{Limitations}

There are several limitations to this research:

1. This research used the experimental method in testing the slippery slope theory, so the case used in experimental treatment still have not reflected the real condition. Thus, there is a need to be careful in generalizing the result of this research.

2. In slippery slope theory, there are two types of taxpayer compliance: voluntary and forced. This result is only focused on the voluntary taxpayer compliance, and so it does not reflect taxpayer's behavior as fully as the slippery slope.

\section{REFERENCES}

[1] Andriawan, D., Sujana, E. and Yasa, INP. (2018). Mengungkap Faktor-Faktor Yang Mendorong Wajib Pajak Buleleng Mengikuti Program Tax Amnesty. Jurnal Ilmiah Mahasiswa Akuntansi Vol.8 No.2 Tahun 2018.

[2] Direktorat Jenderal Pajak Republik Indonesia. (2018). Kepatuhan Wajib Pajak Meningkat diakses dari www.pajak.go.id tanggal 23 Maret 2018

[3] Faizal, S.M., Palil, M.R., Maelah, R. and Ramli, R. (2017). Power and Trust as Factors Influencing Tax Compliance Behavior in Malaysia. Asian Journal of Accounting and Governance, 8, pp.79-85

[4] Gudono. Analisis Data Multivariat. Edisi 4. Yogyakarta: BPFE Yogyakarta, 2015.

[5] Kastlunger, B., Lozza, E., Kirchler, E. and Schabmann, A. (2013). Powerful Authorities and Trusting Citizens: The Slippery Slope Framework and Tax Compliance in Italy. Journal of Economic Psychology, 34, pp.36-45.

[6] Kementerian Keuangan Republik Indonesia. (2018). Struktur Anggaran Pendapatan dan Belanja Negara 2018 diakses melalui www. kemenkeu.go id diakses tanggal 23 Maret 2018 . 
[7] Kirchler, E., Hoelzl, E. and Wahl, I. (2008). Enforced Versus Voluntary Tax Compliance: The "Slippery Slope" Framework. Journal of Economic Psychology, 29(2), pp.210-225.

[8] Mahadianto, MY, and Astuti AP. (2017). Previllage Tax Payer, Sosialisasi Pajak Dan Kepercayaan Pada Otoritas Pajak Terhadap Kepatuhan. Jurnal Kajian Akuntansi, Vol 1, (1), 2017, 77-86.

[9] Nurmantu, Safri. (2007). Faktor- Faktor yang mempengaruhi Pelayanan Perpajakan. Jurnal Ilmu Adminstrasi dan Organisasi,Bisnis \& Birokrasi, Vol.15, No.1 (Januari).

[10] Prinz, A., Muehlbacher, S. dan Kirchler, E. (2014). The Slippery Slope Framework on Tax Compliance: An Attempt to Formalization. Journal of Economic Psychology, 40, pp.20-34.
[11] Ratmono, Dwi. (2014). Model Kepatuhan Pajak Sukarela, Peran Denda, Keadilan Prosedural dan Kepercayaan terhadap Otoritas Pajak. Jurnal Akuntansi dan Auditing Indonesia Vol. 18 No. 1 Tahun 2014, Hal. 42-64.

[12] . (2015). Upaya Peningkatan Kepatuhan Wajib Pajak Pribadi: Penjelasan Teori Slippery Slope. Buletin Ekonomi Vol.13 No. 1, April 2015 Hal. 59-76.

[13] Rustiyaningsih,S. (2011). Faktor-Faktor Yang Mempengaruhi Tingkat Kepatuhan Wajib Pajak. Disampaikan dalam Simposium Nasional Akuntansi (SNA) XI, Pontianak.

[14] Wahl, I., Kastlunger, B. and Kirchler, E. (2010). Trust in Authorities and Power to Enforce Tax Compliance: An Empirical Analysis of the "Slippery Slope Framework". Law \& Policy, 32(4), pp.383-406. 


\section{Attachment:}

\section{Research Instruments \\ PART 1 \\ CASE STUDY}

Read the case below carefully, then give your answer about this case. There is no right or wrong answer, give the answer that suits your personality.

Varosia is a country in Europe with an area of $83.871 \mathrm{~km}^{2}$. Their official language is English. According to the 2017 census, Varosia has a total population of 16.336.000. Unemployment rate in Varosia is still on average. The wage gap between its populations is not huge.

(Below are treatments for high (low) self-efficacy)

Since their independence in 1949, Varosia adopt democratic (authoritarian) governmental system that has high (low) political stability. In their government, Verosia routinely (have never) do public elections to choose the country's leader. Verosia government have good (bad) reputation in the populations' eyes. From the survey, 70\% of the populations are satisfied (unsatisfied) with their government.

Verosia's tax is (not) being distributed evenly to its people with different kinds of income. Varosia people feel that all citizens should (not) contribute to their country by paying their tax. The government of Varosia is really (not) transparent and they (do not) provide free consultation service on their people's tax problems. Other than that, Varosia's public authority have high (low) commitment on public services and is really (not) enthusiast in serving the people.

The country's expenditure could (not) be tracked by the people of Varosia because they routinely (never) give clear information on the tax usage. From an opinion poll in October 2017, 78\% Varosian people think that their tax money is (not) being used well by the government. Also, embezzlement is very rarely (commonly) done by their country's officials. According to International Corruption Index, Varosia is a country with the lowest (highest) corruption rate in Europe. Because of that, the people of Varosia really trust (highly doubt) their government.

(Below is from high (low) power treatment)

In relation with tax code, Varosian law enforcement is really effective (ineffective) on tax evader. Varosian government could do inspection on their people easily (with much effort) to hunt on those tax evader. The government give a huge (low) budget on their tax office. Because of that, the tax officer could (not) employ good tax inspector. The people of Varosia sees that the tax officer in their country to be (not) really active in doing their job.

The possibility of the people being inspected by tax authority is really high (low). Because of that, there are so many (little) tax evader that were being detected. Aside from that, the penalty for tax evader is really high (low). Varosian government (does not) punish all tax evader strictly. Because of that, the Varosian people think that Varosian government is a strong (weak) government.

If you are a people of Varosia, please show your voluntary level in paying your taxes by circling one of the numbers below:

\begin{tabular}{|c|c|c|c|c|}
\hline Very Low & Low & Neutral & High & Very High \\
\hline 1 & 2 & 3 & 4 & 5 \\
\hline
\end{tabular}


PART II

Answer the questions below. Give a check symbol $(\sqrt{ })$ on one of the answer columns.

1. Based on the given case, do the Varaosian believe in their government?

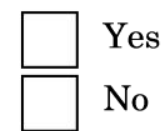

2. Based on the given case, do the Varosian think that their government is a strong one or not?

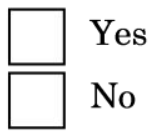

\section{DEMOGRAPHIC DATA}

Please fill in the following demographic data. Give a check symbol on the given box. We guaranteed the confidentiality of your identity.

Name*

Gender

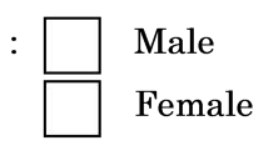

Age

Work status

$\square$
$\square$
$\square$

Have Worked Before

Currently Working

Have Never Worked Before

Are you a taxpayer?

$\square$ Yes
$\square$ No

*optional 